\title{
Pengaruh Pemberian Prebiotik Immuno Forte dengan Level Berbeda terhadap Berat dan Persentase Karkas Ayam Broiler
}

\author{
(Prebiotics Giving Effect Immuno Forte With Different Level \\ of Carcass Weight and Percentage Broiler Chikens)
}

\author{
Yunasri Usman ${ }^{1}$, Herawati Latif, Jaunul Abdillah ${ }^{1}$ \\ ${ }^{1}$ Program Studi Peternakan, Fakultas Pertanian, Universitas Syiah Kuala
}

\begin{abstract}
Abstrak. Penelitian ini bertujuan untuk mengetahui pengaruh pemberian prebiotik Immuno Forte dengan level berbeda terhadap berat dan persentase karkas ayam broiler. Penelitian ini dilakukan di Laboratorium Lapangan Peternakan (LLP) Fakultas Pertanian Universitas Syiah Kuala, Banda Aceh, pada tanggal 22 Agustus sampai 19 September 2015. Penelitian ini menggunakan 100 ekor (DOC) ayam broiler CP 707 Strain Arbor Acres produksi PT. Charoen Pokphand. Ransum yang digunakan adalah ransum komersial R511 Hy-provite priode starter dan R512 Bravo priode finisher. Perlakuan yang diberikan terdiri dari : P0 (0 ml Immuno forte/3 1 air $),$ P1 (0,5 ml Immuno forte/3 1 air), P2 (1 ml Immuno forte/3 1 air), P3 (1.5 ml Immuno forte/3 1 air) dan P4 (2 ml Immuno forte/3 1 air). Rancangan yang digunakan adalah Rancangan Acak Lengkap (RAL) dengan 5 perlakuan dan 4 ulangan. Parameter yang diamati meliputi berat akhir, berat karkas, persentase karkas, berat potongan karkas dan persentase potongan karkas ayam broiler. Hasil penelitian menunjukkan penambahan prebiotik Immuno forte belum memberikan pengaruh positif terhadap berat karkas ayam broiler. Penambahan prebiotik immuno forte dalam air minum berpengaruh nyata terhadap berat sayap, persentase sayap dan berat punggung ayam broiler, namun tidak berpengaruh nyata terhadap berat hidup, berat karkas, persentase karkas, berat dada, persentase dada, berat paha, persentase paha, berat punggung dan persentase punggung ayam broiler umur 28 minggu.
\end{abstract}

Kata kunci : Broiler, Prebiotik, Immuno forte, Karkas.

\begin{abstract}
This study aimed to determine the effect of prebiotics Immuno Forte with different levels of the weight and the percentage of broiler chicken carcasses. This research was conducted at the Laboratory of Animal Husbandry Field (LLP) Faculty of Agriculture, University of Syiah Kuala, Banda Aceh, on August 22 to 19, 2015. This study used 100 individuals (DOC) CP 707 broilers Arbor Acres strain produced by PT. Charoen Pokphand. Rations used was a commercial ration Hy-provite R511 and R512 starter period Bravo period finisher. Treatments consisted of: P0 (0 ml Immuno Forte / 31 water), P1 (0.5 ml Immuno Forte / 31 water), P2 ( $1 \mathrm{ml}$ Immuno Forte / 31 water), P3 (1.5 ml Immuno Forte / 31 water) and P4 (2 ml Immuno forte / 31 water). The design used was completely randomized design (CRD) with 5 treatments and 4 replications. The parameters observed final weight, carcass weight, carcass percentage, pieces of carcass weight and the percentage of broiler chicken carcass pieces. The results showed the addition of prebiotics Immuno Forte has not been a positive influence on broiler chicken carcass weight. The addition of prebiotics immuno forte in drinking water significantly affect the weight of the wing, the percentage of the wings and heavy backs broiler chickens, but did not significantly affect live weight, carcass weight, carcass percentage, heavy chest, the percentage of the chest, heavy thighs, the percentage of thigh, severe back and backs percentage broilers aged 28 weeks.
\end{abstract}

Keywords: Broiler, Prebiotics, Immuno forte, Carcass

\section{PENDAHULUAN}

Salah satu sumber daging yang paling banyak dimanfaatkan oleh masyarakat Indonesia adalah ayam. Daging ayam yang sering dikonsumsi oleh masyarakat diperoleh dari pemotongan ayam broiler, petelur afkir, dan ayam kampung (Dewi, 2014).

Prebiotik sejatinya adalah bahan makanan yang mengandung nutrisi, digunakan untuk mendukung pertumbuhan dan perkembangan bakteri baik yang sudah ada di dalam usus, tujuannya adalah untuk menekan bakteri patogen dengan cara mendominasi perkembangan di dalam usus. Immuno forte adalah produk prebiotik yang mengandung 3 komponen pertahanan yaitu Mannan Oligosaccharide (MOS), beta glucans, dan chitosan yang dibutuhkan unggas (ayam broiler, layer, ayam kampung super, bebek/itik, puyuh, merpati, kalkun dan burung) 
untuk meningkatkan respon imun (kekebalan), meningkatkan ketahanan terhadap beberapa agen patogen dan mikotoksin, serta menjaga kesehatan saluran pencernaan, yang diberikan ke ternak melalui air minum (Royalpoultry, 2013).

Penelitian ini bertujuan untuk mengevaluasi pemberian prebiotik immuno forte yang dicampurkan ke dalam air minum terhadap berat dan persentase karkas ayam broiler.

\section{Hipotesis}

$\mathrm{H}_{0}=$ Pemberian pakan komersil dengan prebiotik immuno forte yang berbeda dalam air minum tidak berpengaruh nyata terhadap berat dan persentase karkas ayam broiler.

$\mathrm{H}_{1}=$ Pemberian pakan komersial dengan prebiotik immuno forte yang berbeda dalam air minum berpengaruh nyata terhadap berat dan persentase karkas ayam broiler.

\section{Deskripsi Ayam Broiler}

Ayam broiler adalah ayam jantan atau betina yang umumnya dipanen pada umur 5-6 minggu dengan tujuan sebagai penghasil daging (Kartasudjana dan Suprijatna, 2006). Ayam yang dipelihara adalah ayam broiler yakni ayam yang dominan berwarna putih dan cepat tumbuh (Rasyaf, 2008). Ayam broiler adalah ayam jantan atau betina yang umumnya dipanen pada umur 5-6 minggu dengan tujuan sebagai penghasil daging (Kartasudjana dan Suprijatna, 2006).

\section{Pakan dan kebutuhan Air Minum}

Suprijatna et al. (2005) Menyatakan pakan adalah campuran dari berbagai macam bahan organik maupun anorganik untuk ternak yang berfungsi sebagai pemenuhan kebutuhan zat-zat makanan dalam proses pertumbuhan.

\section{Prebiotik}

Prebiotik adalah suatu bahan makanan yang tidak dapat dicerna dan memberikan manfaat positif bagi tubuh, karena secara selektif menstimulir pertumbuhan dan aktivitas bakteri baik dalam usus besar (Roberfroid, 2007). Prebiotik yang digunakan untuk pakan ternak adalah karbohidrat yang tidak dicerna oleh tubuh, namun dapat dicerna oleh mikroba yang menguntungkan dalam tubuh, sehingga meningkatkan kesehatan ayam (Anonim, 2013).

\section{Kandungan Immuno Forte}

Immuno forte adalah produk prebiotik yang digunakan untuk ternak yang diberikan melalui air minum. Berdasarkan uraian yang diterapkan pada kemasan, Immuno Forte mengandung 3 komponen pertahanan yaitu Mannan Oligosaccharide (MOS), beta glucans, dan chitosan yang dibutuhkan unggas untuk meningkatkan respon imun, meningkatkan kesehatan saluran pencernaan, mengikat mikotoksin, dan mencegah atau mengurangi stress (Royalpoultry, 2013).

\section{Bobot Hidup}

Bobot hidup adalah bobot yang didapat dengan cara menimbang bobot ayam setelah dipuasakan selama 12 jam. Bobot hidup perlu diperhatikan kualitas dan kuantitas dari ransum yang dikonsumsi, sehingga didapatkan pertumbuhan yang baik (Blakely dan Bade, 1998).

\section{Bobot Karkas}

Karkas broiler adalah daging bersama tulang hasil pemotongan, tanpa darah, setelah dipisahkan dari kepala sampai batas pangkal leher dan dari kaki sampai batas lutut serta isi 
rongga dalam perut ayam. Karkas adalah bagian tubuh ayam tanpa bulu, darah, leher, kaki bagian bawah (cakar) (Ensminger, 1990).

\section{Persentase Karkas}

Karkas merupakan ayam yang telah disembelih, dibersihkan dari bulu dikeluarkan jeroannya, kepala dipisahkan dengan leher hingga batas kaki. Karkas ayam dibuat klasifikasinya berdasarkan bagian-bagian tubuh (Rasyaf, 2003). Siregar et al., (1980) menyatakan karkas yang baik berbentuk padat dan tidak kurus, tidak terdapat kerusakan kulit ataupun dagingnya, sedangkan karkas yang kurang baik mempunyai daging yang kurang padat pada bagian dada sehingga kelihatan panjang dan kurus.

\section{Tempat dan Waktu}

\section{METODE PENELITIAN}

Penelitian ini dilakukan di Kebun Percobaan (Field Lab) Jurusan Peternakan Fakultas Pertanian Univeritas Syiah Kuala Darussalam Banda Aceh. Penelitian ini berlangsung selama 28 hari, mulai tanggal 22 Agustus sampai dengan tanggal 19 September 2015.

\section{Materi Penelitian}

Penelitian ini menggunakan 100 (seratus) ekor day old chicken (DOC) ayam broiler CP 707, produksi PT. Charoen Pokphand Medan, yang dipesan melalui salah satu poultry shop yang ada di Banda Aceh.

\section{Bahan dan Alat}

Bahan yang digunakan dalam penelitian ini terdiri dari ransum komersial (R511 Hy-pro vite dan R512 Bravo). Prebiotik Immuno forte, vaksin Newcastle Disease (ND) berupa Medivac ND La Sota, desinfektan Rodalon, litter, koran bekas, dan kapur.

Peralatan yang digunakan dalam penelitian ini meliputi tempat pakan, tempat minum, chickquard, kandang bersekat ukuran $70 \times 70 \mathrm{~cm}$, dan lampu pemanas masing-masing 20 unit, timbangan, termometer dan peralatan penunjang kandang seperti ember, cangkul, gayung, sprayer, dan kereta sorong masing-masing 1 unit. Untuk keperluan pengamatan berat akhir dan persentase karkas diperlukan peralatan antara lain pisau, ember, telenan, baskom, kertas label, plastik, timbangan dan alat tulis.

\section{Perlakuan}

Penelitian ini menggunakan ransum dasar berupa ransum komersial yaitu R511 Hy-pro vite untuk anak ayam umur 0-3 minggu (starter) dan R512 Bravo untuk anak ayam umur 3-4 minggu (grower /finisher). Penelitin ini menggunakan suplemen prebiotik immuno forte yang dilarutkan dalam air minum masing-masing sebanyak 0.5-2.0 ml/3 1 air. Perlakuan yang dilakukan pemberian $100 \%$ pakan komersil dan prebiotik immuno forte dengan level berbeda.

\section{Rancangan Penelitian}

Rancangan penelitian yang digunakan adalah Rancangan Acak Lengkap (completely randomized design) terdiri dari 5 perlakuan dan 4 ulangan. Setiap ulangan merupakan unit percobaan yang masing-masing terdiri dari 5 ekor ayam. Perlakuan yang diberikan adalah penambahan immuno forte dengan level yang berbeda diteteskan dalam air minum. 
Tabel 1. Bagan Rancangan Penelitian

\begin{tabular}{cccccc}
\hline Ulangan & \multicolumn{5}{c}{ Perlakuan } \\
\cline { 2 - 6 } & P0 & P1 & P2 & P3 & P4 \\
\hline 1 & P0.1 & P1.1 & P2.1 & P3.1 & P4.1 \\
2 & P0.2 & P1.2 & P2.2 & P3.2 & P4.2 \\
3 & P0.3 & P1.3 & P2.3 & P3.3 & P4.3 \\
4 & P0.4 & P1.4 & P2.4 & P3.4 & P4.4 \\
\hline
\end{tabular}

Keterangan :

$\mathrm{P}_{0}=$ Prebiotik immuno forte $0 \mathrm{ml} / 31$ air (kontrol)

$\mathrm{P}_{1}=$ Prebiotik immuno forte $0.5 \mathrm{ml} / 31$ air

$\mathrm{P}_{2}=$ Prebiotik immuno forte $1.0 \mathrm{ml} / 31$ air

$\mathrm{P}_{3}=$ Prebiotik immuno forte $1.5 \mathrm{ml} / 31$ air

$\mathrm{P}_{4}=$ Prebiotik immuno forte $2.0 \mathrm{ml} / 31$ air

\section{Parameter}

Parameter yang diamati dalam penelitian adalah:

-Bobot akhir ayam (gram), bobot karkas (gram), persentase karkas (\%), bobot potongan karkas, persentase potongan karkas (\%)

\section{Analisa Data Penelitian}

Data yang diperoleh dianalisis dengan Analysis of Variance (ANOVA). Dan jika menunjukkan perbedaan dilanjutkan dengan uji Duncan (Steel dan Torrie, 1993).

\section{HASIL DAN PEMBAHASAN}

Pengaruh pemberian Prebiotik Immuno Forte Dengan Level Berbeda Terhadap Kualitas Karkas Ayam Broiler di dalam air terhadap berat akhir dan persentase Karkas ayam broiler pada umur 28 hari diperlihatkan pada Tabel 3.

Tabel 3. Rataan Berat hidup, Berat Karkas dan Persentase Karkas Ayam Broiler yang Diberi Immuno Forte Level Berbeda di dalam Air Minum

\begin{tabular}{lccccc}
\hline \multicolumn{1}{c}{ Karkas } & \multicolumn{5}{c}{ Perlakuan } \\
\cline { 2 - 6 } $\begin{array}{c}\text { Keseluruhan } \\
\text { (WholeCarcass) }\end{array}$ & $\mathrm{P}_{0}$ & $\mathrm{P}_{1}$ & $\mathrm{P}_{2}$ & $\mathrm{P}_{3}$ & $\mathrm{P}_{4}$ \\
\hline Berat & 1587,5 & 1600,0 & 1570,0 & 1565,0 & 1625,0 \\
Hidup (g) & $\pm 29,935$ & $\pm 21,213$ & $\pm 21,213$ & $\pm 25,981$ & $\pm 53,929$ \\
& & & & & \\
Berat & 1168,78 & 1183,09 & 1140,26 & 1143,54 & 1119,96 \\
Karkas (g) & $\pm 17,780$ & $\pm 14,719$ & $\pm 17,927$ & $\pm 21,894$ & $\pm 47,518$ \\
& & & & & \\
Persentase & 73,639 & 73,949 & 72,627 & 73,075 & 73,799 \\
Karkas(\%) & $\pm 0,450$ & $\pm 0,417$ & $\pm 0,535$ & $\pm 0,889$ & $\pm 0,596$ \\
\hline
\end{tabular}




\section{Berat Hidup}

Pemberian immuno forte dalam air minum perlakuan tidak berpengaruh nyata $(\mathrm{P}>0,05)$ terhadap bobot hidup ayam penelitian. Penggunaan ransum $\left(\mathrm{P}_{4}\right)$ terlihat peningkatan lebih baik terhadap bobot hidup ayam jika dibandingkan dengan ransum kontrol $\left(\mathrm{P}_{0}\right)$, namun tidak menunjukan perbedaan yang nyata

\section{Pengaruh Perlakuan Terhadap Berat Karkas dan Persentase Karkas}

Hasil analisis ragam mengenai penggunaan Immuno forte yang dilarutkan dalam air minum tidak menunjukkan perbedaan yang nyata terhadap bobot karkas ayam broiler. Hal ini dikarenakan bobot badan pada perlakuan juga tidak berbeda nyata. Semakin menurunnya bobot badan yang dihasilkan, semakin rendah juga bobot karkas yang dihasilkan.

Persentase karkas ayam broiler yang diberikan immuno forte tidak berbeda nyata $(\mathrm{P}>0,05)$ diduga karena ayam dipanen pada umur yang sama. Dan bobot hidup yang hidup yang hampir sama. Seperti yang dinyatakan Brake et al. (1993) persentase karkas berhubungan dengan jenis kelamin, umur dan bobot hidup.

Tabel 4. Berat dan Peresentase Potongan Karkas Ayam Broiler yang Diberi Imunno Forte dengan Level Berbeda didalam Air Minum.

\begin{tabular}{llllll}
\hline Potongan Karkas & \multicolumn{5}{c}{ Perlakuan } \\
\cline { 2 - 6 } \multicolumn{1}{c}{ Retail Cut) } & \multicolumn{1}{c}{$\mathrm{P}_{0}$} & \multicolumn{1}{c}{$\mathrm{P}_{1}$} & \multicolumn{1}{c}{$\mathrm{P}_{2}$} & \multicolumn{1}{c}{$\mathrm{P}_{3}$} & $\mathrm{P}_{4}$ \\
\hline Berat dada (g) & 418,238 & 401,383 & 395,870 & 374,158 & 429,335 \\
& $\pm 13,725$ & $\pm 9,526$ & $\pm 10,732$ & $\pm 33,477$ & $\pm 18,789$ \\
Persentase dada & 35,576 & 33,929 & 34,712 & 32,752 & 35,767 \\
(\%) & $\pm 0,623$ & $\pm 0,741$ & $\pm 0,675$ & $\pm 2,960$ & $\pm 0,410$ \\
& & & & & \\
Berat sayap (g) & $133,173^{\mathrm{ab}}$ & $136,843^{\mathrm{a}}$ & $115,240^{\mathrm{c}}$ & $124,313^{\mathrm{bc}}$ & $114,313^{\mathrm{c}}$ \\
& $\pm 1,554$ & $\pm 4,023$ & $\pm 3,803$ & $\pm 2,357$ & $\pm 4,854$ \\
Persentase sayap & $11,400^{\mathrm{a}}$ & $11,565^{\mathrm{a}}$ & $10,108^{\mathrm{ab}}$ & $10,881^{\mathrm{a}}$ & $9,549^{\mathrm{b}}$ \\
(\%) & $\pm 0,174$ & $\pm 0,281$ & $\pm 0,308$ & $\pm 0,260$ & $\pm 0,266$ \\
Berat Paha (g) & 324,898 & 317,298 & 322,140 & 313,575 & 323,473 \\
Persentase paha & $\pm 13,891$ & $\pm 5,837$ & $\pm 7,265$ & $\pm 7,937$ & $\pm 10,092$ \\
(\%) & 27,756 & 26,817 & 28,258 & 27,419 & 26,992 \\
& $\pm 0,790$ & $\pm 0,284$ & $\pm 0,562$ & $\pm 0,414$ & $\pm 0,425$ \\
Berat punggung & 280,000 & 323,270 & 300,965 & 301,588 & 324,842 \\
(g) & $\pm 5,667$ & $\pm 8,712$ & $\pm 10,517$ & $\pm 13,575$ & $\pm 16,038$ \\
Persentase & $23,992^{\mathrm{b}}$ & $27,324^{\mathrm{a}}$ & $26,350^{\mathrm{a}}$ & $26,350^{\mathrm{ab}}$ & $27,042^{\mathrm{a}}$ \\
punggung & $\pm 0,819$ & $\pm 0,662$ & $\pm 0,764$ & $\pm 0,862$ & $\pm 0,354$ \\
\hline
\end{tabular}

Keterangan: Superskrip huruf pada baris yang sama menunjukkan perbedaan yang nyata $(\mathrm{P}<0,05)$ 


\section{Berat Dada dan Persentase Dada}

Rataan berat dada dari masing-masing perlakuan dapat dilihat pada Tabel 4. Pemberian immuno forte dengan level berbeda tidak berpengaruh nyata $(\mathrm{P}>0,05)$ terhadap berat dada dan persentase dada. Hal ini diduga karena berat karkas dan persentase karkas juga tidak berbeda.

Persentase dada yang dihasilkan pada masing-masing perlakuan berkisar antara 32,752-35,767\%, Hasil Natamijaya et al. (1999) menambahkan bahwa persentase karkas diperoleh dari bobot karkas, sehingga nilai persentase dipengaruhi langsung oleh bobot karkas.

\section{Berat Sayap dan Persentase Sayap}

Pemberian immuno forte dalam air minum berpengaruh sangat nyata $(\mathrm{P}<0,01)$ terhadap berat sayap ayam penelitian. Hasil uji Duncan menunjukkan $\left(\mathrm{P}_{1}\right)$ memiliki berat sayap nyata lebih tinggi dibandingkan dengan perlakuan lainnya. Sayap adalah bagian karkas yang lebih banyak mengandung jaringan tulang dibandingkan dengan jaringan ototnya, sehingga yang lebih berpengaruh adalah mineral dalam ransum untuk pertumbuhan (Basoeski, 1983).

Hasil uji Duncan menunjukkan bahwa nilai persentase sayap pada perlakuan $\left(\mathrm{P}_{2}\right)$ berbeda sangat nyata $(\mathrm{P}<0,01)$ dengan $\left(\mathrm{P}_{0}, \mathrm{P}_{1}, \mathrm{P}_{3}\right.$ dan $\left.\mathrm{P}_{4}\right)$. Hal ini dapat dipengaruhi oleh suhu kandang yang cukup tinggi sehingga menyebabkan terjadinya stress pada ayam, dan pakan yang dikonsumsi menjadi turun.

\section{Berat Paha dan Persentase Paha}

Rataan berat paha dari masing-masing perlakuan dapat dilihat pada Tabel 4. pemberian Immuno forte dalam air $\left(\mathrm{P}_{0}-\mathrm{P}_{4}\right)$ tidak berpengaruh nyata $(\mathrm{P}>0,05)$ terhadap berat dan persentase paha. Namun dapat terlihat bahwa berat paha tertinggi pada perlakuan $\left(\mathrm{P}_{0}\right)$. Menurut Essary dan Dawson (1965) paha merupakan bagian karkas yang banyak mengandung daging sehingga perkembangannya banyak dipengaruhi oleh kandungan protein pakan.

Rataan persentase paha masing-masing perlakuan dapat dilihat pada Tabel 4. menunjukkan persentase paha tidak berpengaruh nyata $(\mathrm{P}>0,05)$ yaitu berkisar 28,817 $28,258 \%$.

\section{Berat Punggung dan Persentase Punggung}

Pemberian immuno forte dalam air tidak berbeda nyata $(\mathrm{P}>0,05)$ terhadap berat punggung. Meskipun secara statistik tidak berbeda nyata, ayam-ayam broiler yang diberikan immuno forte dalam air minum ada kecenderungan memiliki berat punggung yang lebih tinggi. Nilai tertinggi bobot punggung yaitu pada perlakuan $\left(\mathrm{P}_{4}\right) 324,842$, dan nilai terendah pada perlakuan $\left(\mathrm{P}_{0}\right) 280,000$.

Pemberian immuno forte dalam air minum berpengaruh nyata $(\mathrm{P}<0,05)$ terhadap persentase punggung. Hasil uji Duncan menunjukkan bahwa nilai persentase punggung pada perlakuaan $\left(\mathrm{P}_{1}\right)$ berbeda nyata $(\mathrm{P}<0,05)$ dengan perlakuaan $\mathrm{P}_{0}, \mathrm{P}_{2}, \mathrm{P}_{3}$ dan $\mathrm{P}_{4}$. Rataan persentase punggung ayam broiler selama penelitian berkisar 23,99-27,32\%. 


\section{Kesimpulan}

\section{Kesimpulan}

Berdasarkan hasil penelitian yang telah dilakukan maka dapat diambil kesimpulan bahwa penambahan prebiotik Immuno forte dalam air minum belum memberikan pengaruh terhadap berat dan Persentase karkas ayam broiler.

Penambahan prebiotik immuno forte dalam air minum berpengaruh nyata terhadap berat sayap, persentase sayap dan berat punggung ayam broiler umur 28 minggu.

\section{Saran}

Sebaiknya diperlukan penelitian lanjutan menggunakan prebiotik immuno forte dalam waktu lebih dari 4 minggu agar mendapatkan hasil yang lebih baik khususnya dibagian berat dan persentase karkas ayam broiler.

\section{DAFTAR PUSTAKA}

Anonim, 2013. Probiotik Bagi Ayam.http://ayambroiler.com/tag/prebiotik/. Diakses tanggal 6 Juli 2015.

Basoeki, B.D.A. 1983. Pengaruh Tingkat Peberian Ampas Tahu Dalam Ransum Terhadap Potongan Karkas Komersial Ayam Broiler Betina Strain Hybro Umur Enam Minuggu. Karya Ilmiah Fakultas Peternakan, Institut Pertanian Bogor.

Brake J, Havestein GB, Scheideler SE, Ferket PR, . Rives DV. 1993. Relationship of sex, age and body weight to broiler carcass yield and offal production. Poultry Sci 72:11371145.

Dewi, F.R. 2014. Pengaruh Pemberian Jenis Pakan Yang Berbeda Terhadap Berat Badan Anak Ayam Kampung

Ensminger. M. E. 1990. Poultry Science. $3^{\text {rd }}$ Edition. Interstate Publisher. Inc., Danville.

Essary, E. O. and L. E. Dawson. 1965. Quantity of fryer carcasses as related to protein and fat levels in the diet. Fat deposition and moisture pick-up during chilling. Poultry Sci. $35: 748-755$.

Kartasudjana, R dan Suprijatna, E. 2006. Manajemen Ternak Unggas. Penebar Swadaya. Jakarta.

Natasmijaya, A.G., S.N. Jarmani, U. Kusnadi dan L. Prahrani. 1999. Pengaruh Pemberian Kunyit Curcuma domestica Val. Dan lempuyang Zingiber ammaticum Val. Terhadap bobot badan dan komversi pakan pada broiler. Pros. Seminar Nasional Peternakan dn Veteriner, Bogor, 18-19 Oktober 1999. Puslitbang Peternakan, Bogor. Hlm. 332-335.

Rasyaf, M. 2003. Beternak Ayam Pedaging. Penerbar Swadaya. Jakarta.

Rasyaf, M. 2008. Panduan Beternak Ayam Pedaging. Penerbar Swadaya. Jakarta.

Roberfroid, M.B. 2007. Prebiotics: The Concept Revisited. J. Nutr. 137: 830S.

Royalpoultry. 2013. Immuno Forte Prebiotik (prebiotic) untuk Meningkatkan Daya Tahan Tubuh Unggas dari Stres dan Penyakit. Http://royalpoultry.co/blog/2013/12/01/immuno-forte-prebiotik. Diakses 25 Juni 2015.

Siregar, A. P., M. Sabrani and P. Sunyoto. 1980. Teknik Beternak Ayam Pedaging di Indonesia. Penerbit Margie Group, Jakarta.

Steel, R.G.D. and J.H. Torrie. 1993. Prinsip dan Prosedur Statistika: Suatu Pendekatan Biometrik. Penerbit PT Gramedia Pustaka Utama Jakarta.

Suprijatna, E,. U. Atmomarsono, dan P. Kartasudjana. 2005. Ilmu Dasar Ternak Unggas. Cetakan ke-1. Penebar Swadaya. Jakarta. 